\title{
Mixed Flora
}

National Cancer Institute

\section{Source}

National Cancer Institute. Mixed Flora. NCI Thesaurus. Code C120707.

The presence of more than one fungal and/or bacterial org anism in a culture. 